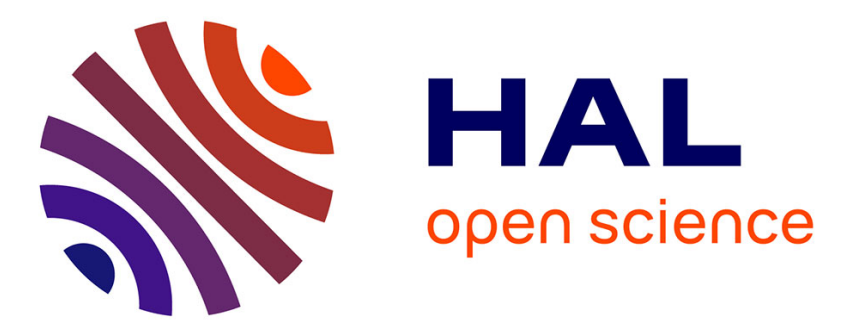

\title{
Aggregate size effect on the development of cementitious compounds in a lime-treated soil during curing
}

\author{
Yejiao Wang, Myriam Duc, Yu-Jun Cui, Anh Minh A.M. Tang, Nadia \\ Benhamed, Wen Jing Sun, Wei-Min Ye
}

\section{- To cite this version:}

Yejiao Wang, Myriam Duc, Yu-Jun Cui, Anh Minh A.M. Tang, Nadia Benhamed, et al.. Aggregate size effect on the development of cementitious compounds in a lime-treated soil during curing. Applied Clay Science, 2017, 136, pp 58-66. 10.1016/j.clay.2016.11.003 . hal-01448173

\section{HAL Id: hal-01448173 \\ https://hal.science/hal-01448173}

Submitted on 26 Apr 2018

HAL is a multi-disciplinary open access archive for the deposit and dissemination of scientific research documents, whether they are published or not. The documents may come from teaching and research institutions in France or abroad, or from public or private research centers.
L'archive ouverte pluridisciplinaire HAL, est destinée au dépôt et à la diffusion de documents scientifiques de niveau recherche, publiés ou non, émanant des établissements d'enseignement et de recherche français ou étrangers, des laboratoires publics ou privés. 


\section{Aggregate size effect on the development of cementitious compounds in a}

\section{2 lime-treated soil during curing}

3

4 Yejiao WANG ${ }^{1}$, Myriam DUC ${ }^{2}$, Yu-Jun CUI ${ }^{1}$, Anh Minh TANG ${ }^{1}$, Nadia BENAHMED $^{3}$, Wen $5 \quad$ Jing $\mathrm{SUN}^{4}$, Wei Min $\mathrm{YE}^{5}$

6

7 1: Ecole des Ponts ParisTech, U.R. Navier/CERMES, 6 - 8 av. Blaise Pascal, Cité Descartes,

8 Champs - sur - Marne, 77455 Marne - la - Vallée cedex 2, France

9 2: Université Paris Est, IFSTTAR/GERS/SRO, 14-20 boulevard Newton - Champs-sur-Marne,

1077447 Marne-la-Vallée, France

11 3: Irstea, Unité de Recherche RECOVER / Equipe G2DR, 3275 route Cézanne, CS 40061, 1213182 Aix En Provence Cedex 5, France

$14^{4}$ : Department of Civil Engineering, Shanghai University, 99 Shangda Road, Shanghai 200444, 14 China

15 : Key Laboratory of Geotechnical and Underground Engineering of Ministry of Education, 16 Tongji University, Shanghai 200092, China

\section{Corresponding author:}

19 Myriam DUC

20

E-mail: myriam.duc@ifsttar.fr 


\section{Abstract}

This work aims to investigate the aggregate size effect on changes in mineralogical composition and microstructure of lime-treated compacted soils. Three soil powders with different maximum aggregate sizes $\left(D_{\max }=5,1\right.$ and $\left.0.4 \mathrm{~mm}\right)$ were prepared prior to the treatment with $2 \%$ of lime. X-ray diffraction (XRD), environmental scanning electron microscope (Env. SEM) coupled with chemical analysis using energy dispersive X-ray spectrometry (EDX) and mercury intrusion porosimetry (MIP) were used to analyse untreated and treated samples at various curing times. Crystallized C-S-H on tobermorite form was identified in the lime-treated soil prepared with large aggregates after one year curing, and an evident increase in nanopores less than $0.1 \mu \mathrm{m}$ C-S-Hwas also observed due to C-S-H creation. By contrast, in the case of smaller aggregates, no obvious C-S-H peaks were observed by XRD technique after the same curing time, even though some evidence of such phases are provided by Env. SEM coupled to EDX analysis. But a large amount of undetectable nanopores less than $6 \mathrm{~nm}$ (considering the MIP technical limitation) was supposed to be formed and could be attributed to the creation of nanocrystallized $\mathrm{C}-\mathrm{S}-\mathrm{H}$ or poorly-crystallized C-S-H (that may fill the pores larger than $2 \mu \mathrm{m}$ ). Such type of C-S-H phases occurred when lime was coated in thin layer on the large surface associated to lime-treated soil prepared with small aggregates.

Keywords: lime-treated soil; aggregate size; curing time; mineral composition; microstructure 


\section{Introduction}

Lime treatment is an effective soil improvement technique widely applied in the field of construction. It largely modifies the soil geotechnical properties through the physico-chemical reactions within the lime-soil-water system (Boardman et al., 2001; Russo, 2005; Al-Mukhtar et al., 2010; Tang et al., 2011; Tran et al., 2014). When quicklime (CaO), soil and water are mixed together, hydration and ionization of quicklime immediately take place. Then, the $\mathrm{Ca}^{2+}$ ions in the pore water released by calcium hydroxide $\left(\mathrm{Ca}(\mathrm{OH})_{2}\right)$ is adsorbed by ion-exchange at clay minerals surface. The diffuse hydrous double layer surrounding the clay particles can be modified by the $\mathrm{Ca}^{2+}$ ion-exchange process, resulting in the flocculation-agglomeration of clay particles (Bell, 1996). These modifications of clay particles induced by lime addition will largely improve the workability of soil by reducing the plasticity, the swelling and shrinkage (Bell, 1989; Russo, 2005). In the long-term, the main reactions between lime and clay minerals are of pozzolanic nature which contributes significantly to the improvement of soil mechanical behaviour in terms of shear strength, shear modulus, compression strength and compressibility (Rajasekaran and Narasimha Rao, 2002; Khattab et al., 2007; Consoli et al., 2009; Tang et al., 2011; Dong, 2013). The mechanical improvement is to be attributed to the creation of cementitious compounds generated by the pozzolanic reaction, coating the soil particles and bonding them together (Bell, 1996; Onitsuka et al., 2001; Nalbantoglu, 2006).

Mineralogical studies of cementitious compounds have been undertaken in recent years. The cementitious compounds can be of various forms due to the different mineralogical composition of soils containing mainly clay minerals such as kaolinite, montmorillonite or illite, and other minerals like quartz and feldspars. Generally, the main cementitious 
compounds are calcium silicate hydrate $(\mathrm{C}-\mathrm{S}-\mathrm{H})$, calcium aluminate hydrate $(\mathrm{C}-\mathrm{A}-\mathrm{H})$ and calcium alumino-silicate hydrate (C-A-S-H) (Khattab, 2002; Rios et al., 2009; Maubec, 2010; Al-Mukhtar et al., 2010). For lime-kaolinite mixture, the production of C-S-H, C-A-H and C-A-S-H was reported by many researchers (Goldberg and Klein, 1952; Eades and Grim, 1960; Glenn and Handy, 1963; Willoughby et al., 1968; Bell 1996). C-S-H and C-A-H were also detected in the lime-treated montmorillonite (Bell 1996; Hilt and Davidson, 1960). Arabi and Wild (1989) noted that C-S-H hydrates were present in the lime-treated marls containing illite, quartz and feldspar. Eades et al. (1962) also identified the production of C-S-H in the lime-treated quartz.

Even though many studies were performed on lime-treated soils, most of them focused on the lime-treated soil samples prepared in the laboratory. However, often lower performance of lime-treated soils and poor durability of lime treatment are observed in the field conditions. Puppala et al. (2006) reported about $40 \%$ lower for stiffness and 20 to $30 \%$ lower for strength in the case of treatment in field. Similar results were reported by other researchers (Horpibulsuk et al., 2006; Kavak and Akyarh, 2007). Additionally, higher hydraulic conductivity and swelling potential of lime-treated soils in the field conditions were observed (Bozbey and Guler, 2006; Cuisinier and Deneele, 2008). There are several factors that can contribute to this difference between field and laboratory conditions. In addition to the climatic factors, especially the wetting/drying cycles and freezing/thawing cycles (Pardini et al., 1996; Guney et al., 2007; Tang et al., 2011; Stoltz et al., 2012), the aggregate size may play an essential role in the hydro-mechanical behaviour of lime-treated soils (Tang et al., 2011, Wang et al. 2015). The bender elements testing performed on the lime-treated samples 
prepared with different maximum aggregates sizes $\left(D_{\max }=5,2,1\right.$ and $\left.0.4 \mathrm{~mm}\right)$ revealed that lime-treated soils prepared with larger maximum aggregate size presented a relatively lower stiffness (Tang et al., 2011). Dong (2013) also indicated that the lime-treated soil prepared with larger aggregates was more sensitive to wetting/drying cycles. Note that aggregates are assemblages of adjacent soil particles in which the cohesive forces are larger than the disrupting force (Kemper and Chepil, 1965). In the field construction, the scarifying/pulverizing process is performed before the lime treatment to control the soil aggregate size. However, the size of soil aggregates in the field can still reach several centimetres, which is much larger than that of soil aggregates prepared in the laboratory before sample reconstruction. In the laboratory, natural tested soils are usually air-dried, ground and sieved into few millimetres. For example, Du et al. (2014) who studied the engineering properties and microstructure of the cement-stabilized contaminated soil, prepared the samples with kaolin clay which had a maximum aggregate size lower than $2 \mathrm{~mm}$; while Cai et al. (2015) used reactive magnesia to treat in the laboratory a silty soil with the same maximum aggregate size. Jiang et al. (2016) also reported that the used soil was first passed through the sieve with $0.5 \mathrm{~mm}$ size prior to treatment.

As the improvement in the mechanical behaviour of soils by lime treatment is proven to be primarily controlled by the cementitious compounds from the pozzolanic reactions, it is expected that the different behaviours of treated soils with various aggregate sizes can be also interpreted from mineralogical analysis. However, no studies have been conducted on this aspect. This constitutes the main objective of the present work. In this study, three different maximum aggregates sizes $\left(D_{\max }=5,1\right.$ and $\left.0.4 \mathrm{~mm}\right)$ of soil powders were prepared before 
112 lime treatment. The creation of cementitious compounds was investigated by X-ray diffraction

113 (XRD). In addition, environmental scanning electron microscope coupled with energy

114 dispersive X-ray spectrometry (Env. SEM-EDX) and mercury intrusion porosimetry (MIP)

115 were applied to investigate the microstructure and chemical composition of the treated soils.

\section{Materials and methods}

The tested soil was taken in Héricourt (France). It is a plastic silt with a clay-size fraction of $27 \%$. The basic geotechnical properties of this silt given by Wang et al. (2016) are listed in Table 1. This soil corresponds to a silt of high plasticity $(\mathrm{MH})$ following the Unified Soil Classification System (USCS). To prepare soil powders with different maximum aggregate sizes, natural soil was first air-dried, gently ground to crush the block of soil and passed through three target sieves (their maximum diameters, $D_{\max }$, are 5, 1 and $0.4 \mathrm{~mm}$, respectively). The large aggregates which could not pass through the sieve were ground manually until all particles passed through, ensuring no changes in mineralogical compositions during sieving (Tang et al., 2011). Afterwards, soil powders S5, S1 and S0.4 are obtained, with $D_{\max }$ equal to $5 \mathrm{~mm}$ for S5, $1 \mathrm{~mm}$ for $\mathrm{S} 1$, and $0.4 \mathrm{~mm}$ for S0.4. Figure 1 shows the aggregate size distributions of the three soil powders, determined by dry sieving. Quicklime was used in this study and it has a high purity with a $\mathrm{CaO}$ content as high as $97.3 \%$. Particle size analysis shows that $82.7 \%, 95.2 \%$ and $100 \%$ of this lime could pass through $80 \mu \mathrm{m}, 200 \mu \mathrm{m}$ and $2 \mathrm{~mm}$ sieves, respectively (Dong, 2013). A lime content of $2 \%$ by mass was selected as binder dosage.

The dry soils were firstly mixed thoroughly with $2 \%$ quicklime. Then, distilled water was added by spray into the dry soil-lime mixture to obtain the target water content $(w=17 \%$, dry 
side of the optimum according to the proctor curve). Static compaction was performed after a mellowing period of 1 hour, to prepare soil samples at the target density $\left(\rho_{d}=1.65 \mathrm{Mg} / \mathrm{m}^{3}\right)$. The samples were carefully wrapped by plastic membrane and scotch tape immediately after compaction. The well-covered sample was stocked in a hermetic box for curing in a chamber at a temperature of $20 \pm 2{ }^{\circ} \mathrm{C}$. Prior to mineralogical and microstructural analyses, the samples were freeze-dried following the procedure proposed by Delage and Pellerin (1984).

$\mathrm{X}$-ray diffraction (XRD) analysis was performed on both untreated and treated samples. To prepare soil powder for this analysis, freeze-dried and oven-dried samples were crushed and ground to pass through a $32 \mu \mathrm{m}$ sieve. After sieving, soil powders were mixed well manually in agate mortar and sprinkled gently in XRD sample holder using a $65 \mu \mathrm{m}$ sieve. The top layer was removed carefully by cutting the surface with a thin razor blade leading to a smooth surface without compaction (such preparation allows to decrease the preferential orientation of clay particles). XRD patterns were obtained using a D8 Advance diffractometer from Bruker ( $\theta-\theta$ configuration, Cobalt anode, $E=35 \mathrm{kV}, I=40 \mathrm{~mA}$, no monochromator, LynxEye detector). A continuous scan mode, between 3 and $80^{\circ} 2$ theta, at a rate of $1 \mathrm{~s}$ per $0.01^{\circ} 2$ theta was selected. Diffractograms were exploited with EVA program coupled with the ICPdf2 mineralogical database.

Environmental scanning electron microscope (Env. SEM, Quanta 400 from FEI company) coupled with energy dispersive X-ray spectrometry (EDX from EDAX company) was employed to observe the microstructure and to study the chemical composition of treated samples. The EDX probe which provides an order of magnitude of the chemical content of elements such as $\mathrm{Ca}, \mathrm{Si}$ and $\mathrm{Al}$ was calibrated before the observations. Images were collected 
on fresh fractured surface after freeze-drying. Secondary or back scattered electron mode was selected in low vacuum mode (no metal coating was applied before observation).

The mercury intrusion porosimetry (MIP) test was carried out on freeze-dried samples. The applied pressure ranged from $3.4 \mathrm{kPa}$ to $230 \mathrm{MPa}$. The corresponding mercury intrusion diameter varied from $0.006 \mu \mathrm{m}$ to $355 \mu \mathrm{m}$. In the analysis, the surface tension of mercury was taken equal to $0.485 \mathrm{~N} / \mathrm{m}$ and the contact angle of mercury was taken equal to $130^{\circ}$.

Table 2 presents the test program. All the $2 \%$ lime-treated samples were freeze-dried before test except a piece of treated sample S1 after 1-year curing that was oven-dried at $105{ }^{\circ} \mathrm{C}$ prior to testing. Untreated soil sample was also tested by XRD to obtain data as reference.

\section{Experimental results}

\subsection{Mineralogical analysis}

Figure 2 shows the XRD patterns of untreated soil and lime-treated soil S1 after 1-year curing. The results illustrate that the main minerals in untreated soil are quartz and clays with the presence of calcite and feldspars. The identification of clay minerals confirms the presence of kaolinite $(d \sim 7 \AA)$, illite/muscovite $(d \sim 10 \AA)$, and montmorillonite $(d \sim 12-14 \AA)$. This clay composition is consistent with previous analyses made by Deneele and Lemaire (2012), who studied the same soil as that used in this study. The reflections associated with these clay minerals (with quite similar intensity or position) are also present in the lime-treated soil. For the lime-treated soil S1 ( $t=1$ year) after freeze-drying, one new reflection at 2 theta equal to $34.2^{\circ}(d \sim 3.04 \AA)$ is identified, suggesting creation of the C-S-H phase. This C-S-H phase would correspond to the main peak of synthetic tobermorite $9 \AA$ with the formula $5 \mathrm{Ca}_{0.65} \mathrm{SiO}_{2}$, 
2.5 $\mathrm{H}_{2} \mathrm{O}$ (Pdf file 010-0374) or to the calcium silicate hydrate $\mathrm{Ca}_{1.55} \mathrm{SiO}_{3.5} \times \mathrm{xH}_{2} \mathrm{O}$ (Pdf file 033-0306). In order to remove the doubt of interpretation related to possible confusion among the phases of unreacted $\mathrm{CaO}, \mathrm{C}-\mathrm{S}-\mathrm{H}$ (tobermorite and other $\mathrm{C}-\mathrm{S}-\mathrm{H}$ forms) and magnesian calcite, the XRD pattern of treated soil S1 after oven-drying at $105^{\circ} \mathrm{C}$ was also collected.

The new peak previously observed disappeared which tends to validate the identified C-S-H phase. Indeed, oven-drying at $105{ }^{\circ} \mathrm{C}$ may dehydrate the C-S-H as suggested by Taylor (1997). Gallé (2001) mentioned also that C-S-H decomposition starts at low temperatures and C-S-H can be partially dehydrated at $105^{\circ} \mathrm{C}$, and then its crystallized structure disappears. Rio et al. (2009) also observed that different stages of C-S-H dehydration took place at a temperature in the range from 100 to $250{ }^{\circ} \mathrm{C}$. If oven-drying at $105{ }^{\circ} \mathrm{C}$ can cause $\mathrm{C}-\mathrm{S}$-H degradation, it is not the case for the magnesium calcite. Indeed, this latter remains stable under temperature effect because decarbonation of calcite occurs at high temperatures (over $700{ }^{\circ} \mathrm{C}$ ) according to Collier et al. (2008), Rios et al. (2009) and Al-Mukhtar et al. (2014). If the new peak observed on XRD pattern was calcite, this peak would remain present whatever the sample preparation. It was obviously not the case. Moreover, the absence of new peak at $d \sim 3.04 \AA$ at short curing time (after just 1-day curing) allows excluding the presence of unreacted $\mathrm{CaO}$ after 1-year curing.

Except the C-S-H phase, other minerals in the lime-treated soil seem similar to those of the untreated sample. Note that the crystallized silicate source used to form C-S-H phase could not be clearly identified by XRD because no clear peak decrease was detected, which would signify its dissolution.

The effect of curing time and aggregates size can be specifically observed in a smaller range 
from $31^{\circ}$ to $39^{\circ} 2$ theta where the C-S-H phase involved on the XRD patterns. The results of treated samples S5 and S0.4 are illustrated in Figure 3a and 3b. Similarly to S1, S5 (Figure 3a) also showed an XRD peak associated with the creation of C-S-H in the case of 1-year curing. However, no sign of C-S-H was detected on the sample after a curing time of $t=60$ days. Surprisingly, no C-S-H reflection was detected on the XRD pattern of treated soil S0.4 after 1 year curing (Figure 3b). This point will be further discussed.

\subsection{Microstructure observation and chemical composition analysis}

Figures $4 \mathrm{a}-\mathrm{c}$ present the distribution maps of silicon, aluminium and calcium derived from EDX coupled with Env. SEM observations on treated soil S1 at a curing time of $t=1$ day. The two first elements belong to aluminosilicates phases such as feldspar and clays.

Areas with high concentration of $\mathrm{Si}$ in Figure $4 \mathrm{a}$ indicate the presence of quartz grains. The calcium distribution map (Figure 4c) is established to localize hydrated lime after short curing time (in this case, $\mathrm{Ca}^{2+}$ has not enough time to diffuse homogeneously into soil aggregates) and the product of lime reaction such as C-S-H (at long time of curing). Even though the protocol to mix the soil with lime was optimized to cover all the soil aggregates, calcium seems to be distributed heterogeneously or rather, some aggregates of hydrated lime appears clearly after 1 day of curing in isolated clusters of several micrometers (Figure 4d). It is however worth noting that isolated small hydrated lime particles below the micron scale cannot be distinguished by Env. SEM. The observations do not allow the detection of the initial soil aggregate border formed by lime coating, whereas slight and continuous borders composed by lime are expected on EDX mapping.

On lime-treated soil S1 after 1-year curing (Figure 5), the calcium distribution map (Figure 5c) 
helps to localize the new pozzolanic products as shown in Figure 5d. New phases generally present a typical water sensitive morphology of $\mathrm{C}-\mathrm{S}-\mathrm{H}$ particles characterised by a soft, porous and rounded texture. Such C-S-H phases can be visually detected by operator on Env. SEM images, only when their sizes are large enough to be distinguished, due to the limited resolution of the Env. SEM apparatus applied in this study. If C-S-H phases are present in particle form (but in a size smaller than $1 \mu \mathrm{m}$ ) or in form of thin gel layer, these C-S-H phases are invisible for the operator. However, the C-S-H phases may be present by means of either coating the soil aggregates, or filling the inter-aggregate pores, or binding the adjacent aggregates together.

Finally, even though the XRD did not detect crystallized C-S-H in the lime-treated soil S0.4 after 1-year curing time, the Env. SEM observation revealed local presence of C-S-H particles as shown in Figure 6. The low quantities of such large C-S-H particles may explain the result. Quantitative EDX analyses complete the Env. SEM observations. Spot analysis at $E=20 \mathrm{kV}$ were performed on areas situated on the EDX mapping in Figures 4 and 5 considering their high calcium content. Table 3 gives the atomic percentages of the main elements present in such areas compared to the atomic percentage measured on natural soil before lime addition and in the areas far from the selected calcium spot. The calculated atomic ratio $\mathrm{Ca} / \mathrm{Si}$ is equal to 2.49 in areas rich in $\mathrm{Ca}^{2+}$ in soil $\mathrm{S} 1$ at $t=1$ day while far from such area the $\mathrm{Ca} / \mathrm{Si}$ ratio is equal to 0.06 (with $\mathrm{Si} / \mathrm{Al}=2.16$ ). Far from the calcium rich areas, the $\mathrm{Ca} / \mathrm{Si}$ ratio remains stable (or increases slightly to 0.09 ) even after 1 year of curing. In soil S1 at $t=1$ day, the area rich in calcium is associated with local hydrated lime particles $\mathrm{Ca}(\mathrm{OH})_{2}$. These particles surround soil aggregates and calcium can be expected to diffuse into these aggregates. Note 

kaolinite, illite and montmorillonite, respectively (and the $\mathrm{Ca} / \mathrm{Si}$ ratio is normally close to 0.07 in montmorillonite).

After a long time curing (1 year) and for any aggregate size, examination of the chemical composition given by EDX on the new formed phase corresponding to C-S-H shows a decrease and an increase of the calcium and silicon contents, respectively, as compared to the initial spot analysis on hydrated lime particles. The $\mathrm{Ca} / \mathrm{Si}$ ratio measured on $\mathrm{C}-\mathrm{S}-\mathrm{H}$ particles is about $0.65-0.63$ (while $\mathrm{Si} / \mathrm{Al}$ is close to 2.16 or 2.32 ) and this ratio is in accordance with the composition of synthetic tobermorite $9 \AA\left(\mathrm{Ca}_{0.65} \mathrm{SiO}_{2}, 2.5 \mathrm{H}_{2} \mathrm{O}\right)$ found by XRD. This is also in agreement with the observations by Brunauer (1962) and El-Hemaly et al. (1977) suggesting a minimum value of 0.8-0.9 for C-S-H gel produced in the mixture of lime-silica-water. Studies of crystal structures of "tobermorites" (Merlino et al. 1999, 2000, 2001) showed that tobermorite is a series between two endmembers, $\mathrm{Ca}_{4} \mathrm{Si}_{6} \mathrm{O}_{15}(\mathrm{OH})_{2} \cdot 5 \mathrm{H}_{2} \mathrm{O}$ and $\mathrm{Ca}_{5} \mathrm{Si}_{6} \mathrm{O}_{17} \cdot 5 \mathrm{H}_{2} \mathrm{O}$, the $\mathrm{Ca} / \mathrm{Si}$ ratio varying between 0.66 and 0.83 . Wild et al. (1986) also stated that hydration of cement at room temperature created a poorly crystallized $\mathrm{C}-\mathrm{S}-\mathrm{H}$ gel with a high $\mathrm{Ca} / \mathrm{Si}$ ratio of about 1.5 but the similar C-S-H gel from the reaction in the lime-silica-water mixture had a lower $\mathrm{Ca} / \mathrm{Si}$ ratio.

\subsection{Pore size distribution}

Results obtained from MIP tests on the lime-treated soils (S5, S1 and S0.4) during a curing time from 7 to 90 days are presented in Figure 7. Data obtained on soils S5 and S0.4 have been presented previously in Wang et al. (2015). The pore size distributions of all lime-treated 
population of macro-pores (inter-aggregate pores) and a population of micro-pores

(intra-aggregate pores). Note that the delimitation of the pore entrance diameter between the macro-pores and micro-pores is defined as $d=2 \mu \mathrm{m}$ in this study (Romero et al., 2011). Generally, macro-pores (larger than $2 \mu \mathrm{m}$ ) are greatly impacted during compaction by the aggregate size: the larger the aggregate size is, the larger the modal entrance size of the macro-pores appears while aggregate size has negligible effect on the micro-pores (smaller than $2 \mu \mathrm{m}$ ) (Wang et al., 2015). As an illustration, the modal size of macro-pores for the untreated sample S5 is around $73 \mu \mathrm{m}$ and in comparison, lower value is obtained for the untreated S0.4 soil with a main pore family around $14 \mu \mathrm{m}$. Nevertheless, these untreated samples with different $D_{\max }$ values share a similar modal size of micro-pores. The mean value of the pore entrance diameter of the micro-pore family remains around $0.3-0.4 \mu \mathrm{m}$, as seen in Figure 7.

Lime treatment progressively impacts the microstructure of soil. The quantity of each pore population was given as the ratio of intruded void ratio to the total void ratio equal to $e=0.68$ (Wang et al., 2016), as illustrated in Table 4. For treated soil S5, an increase in the frequency of the entrance pore diameters between 0.006 and $0.1 \mu \mathrm{m}$ (defined as "nano-pores" in the following text for clarity) can be observed in Figure 7a at a curing time of $t=90$ days, compared with that after 7-day curing. Particularly, the nano-porosity of sample S5 after 90-day curing is $27 \%$ larger than that of the sample after 7-day curing. Less change took place for macro-pores, except a slight decrease in the modal size of macro-pores. The total intrusion value measured on S5 in Figure 7b seems quite similar for the two curing periods. As illustrated in Figure 7c, similar results are observed on treated soil S1: after 90-day curing, 
a small increase (around $14 \%$ ) in the frequency of nano-pores ranging from 0.006 to $0.1 \mu \mathrm{m}$ is detected and the cumulative intrusion curve of $\mathrm{S} 1$ at 90 days is similar to that at 7 days. In the case of sample S0.4, a slight increase of $16 \%$ in the quantity of the nano-pores is also detected for the sample after 90-day curing, in comparison with the sample at 7-day curing. In addition, both modal sizes of macro-pores and micro-pores shift slightly to lower values, by keeping similar shape during curing and decreasing both the quantities of macro-pores and micro-pores, as seen in Figure 7e. It is worth noting that the total intrusion value of S0.4 at 90 days decreases significantly compared with that at 7 days, induced by a reduction of both the modal pore entrance size and the quantity of the large macro-pores (in Figure 7f).

\section{Discussion}

Pozzolanic reactions occur with $2 \%$ lime added to the soil from Héricourt that contains quartz, feldspar and clays, and these reactions are strongly time-dependent. New crystallized phase appeared after a long time of curing (at least 1 year) and the main reflection characterizing this new phase is positioned at $34.2^{\circ}$ (2 theta $\operatorname{CoK} \alpha$ ) (corresponding to $d=$ $3.04 \AA$ ), close to the main peak of calcite that is present in untreated soil. Comparison of XRD patterns of treated soil S1 after 1-year curing and after oven-drying (at $105{ }^{\circ} \mathrm{C}$ ) or after freeze-drying demonstrated that the new peak at $d=3.04 \AA$ corresponds to the crystallized C-S-H phase (probably at tobermorite $9 \AA$ ) (see Figure 2). The chemical analysis on the C-S-H phase by means of Env. SEM-EDX, gave a Ca/Si ratio equal to $0.63-0.65$ for both S1 and S0.4, in agreement with the tobermorite $9 \AA$ composition. No significant reflection corresponding to C-S-H was detected at a curing time of $t=60$ days. This can be explained by the absence of well crystallized C-S-H or by the low detection limit of XRD technique. 
Indeed, it is difficult to detect any crystalline phase if it is poorly crystallized, amorphous, or

310 when its quantity is too small, generally below 0.5-1 \% (Carter et al., 1987; Mitchell, 1993; Moon et al., 2004). In other words, very low quantity of well-crystallized C-S-H phase or amorphous C-S-H gel may be formed at 60 days, whatever the aggregate size.

However, at a long curing time ( $t=1$ year), the aggregate size seems to impact significantly on the pozzolanic reactions among the lime-soil-water system. C-S-H phase can be detected on the treated soil prepared with large aggregates, such as S5 and S1 while crystallised C-S-H are difficult to be observed by XRD technique on soil with small aggregates (as seen in S0.4) even though Env. SEM pictures revealed the presence of isolated C-S-H particles in big

clusters as for S0.4. Note that the low frequency of such clusters, or the low degree crystallisation of C-S-H phase in S0.4, explains why they were not detected by XRD. Furthermore, when lime powder was mixed with small-sized soil aggregates such as S0.4, a thin layer of lime-aggregate (named transition zone by Ping et al. (1991)) was expected due to the large contact surface of small aggregates. On the contrary, lime powders can be locally concentrated in thick layer on the surface of large aggregates (such as those in S1 and S5) which induce small contact surface area. This is consistent with the experimental results of Ping et al. (1991), who studied the aggregate size effect on the transition zone between granular aggregate and cement paste. The authors reported that the thickness of transition zone decreases with the decrease of the aggregate size. As curing time increased, this area where lime is concentrated is in favour of the formation of larger well-crystallized C-S-H particles. Conversely, a more homogeneous lime distribution in S0.4 should induce either the creation of a poorly-crystallized or amorphous C-S-H phase or gel, or a nanometric 
well-crystallized C-S-H particle which is hardly detected by XRD. Even though in S0.4, these C-S-H phases cannot be directly detected by XRD and only localised C-S-H phases were observed by Env. SEM. The appearance of these C-S-H phases was indirectly confirmed by Tang et al. (2011) who conducted bender element tests on lime-treated soils with different aggregate sizes They reported a higher stiffness for the lime-treated soil with $D_{\max }=0.4 \mathrm{~mm}$ at a long curing, compared to that with $D_{\max }=5 \mathrm{~mm}$. Comparison with the untreated sample showed that the treated samples had a higher stiffness, whatever the aggregate size. Cementitious compounds bond the soil particles together, inducing the increase of the soil stiffness.

Furthermore, the aggregate size effect on the microstructure of treated soil is also consistent with previous mineralogical analysis. A relatively larger increase in frequency was observed for the nano-pores ranging from 0.006 to $0.1 \mu \mathrm{m}$ on treated soil with large aggregates, especially for S5 after long curing time. These nano-pores can be attributed to the formation of well-developed C-S-H phase (a hydrated lamellar structure). This formation was favoured by the thick coating of lime around soil aggregates or by the local lime concentration in clusters as observed by Env. SEM. Similar observations were made by Russo and Modoni (2013) who reported that a pore population of $0.007-0.2 \mu \mathrm{m}$ was developed in a lime-stabilised soil at long term. Alvarez et al. (2013) found a small amount of pores below $0.02 \mu \mathrm{m}$, ascribed to C-S-H gel pores. In this study, the formation of C-S-H lead to the creation of nano-pores ranging from 0.006 to $0.1 \mu \mathrm{m}$, as observed in the mixture of lime and soils with large aggregates (S5). Such new nano-porous compounds filled the micro-pores (0.1 to $2 \mu \mathrm{m})$, decreasing the frequency of these micro-pores. However, less quantity of 
nano-pores was found in treated soil S0.4 at the same curing period. While a large reduction in the total intrusion value of S0.4 at 90 days was identified, indicating that more undetectable nano-pores were created (their sizes are lower than $0.006 \mu \mathrm{m}$ that corresponds to the detection limit of MIP measurement in this study), since the initial void ratio of the sample remains identical (Wang et al., 2016).. These undetectable nano-pores are mainly associated with C-S-H phases, which were generated from the pozzolanic reactions in S0.4 sample. This also agrees with the hypothesis of the formation of nano-crystalline C-S-H or small-sized amorphous C-S-H gels, which is invisible by XRD technique and whose nano-pores are undetectable by MIP measurement. Furthermore, these C-S-H phases in S0.4 soil gradually cover the surface of small soil particles to a large extent, bond the adjacent soil particles together, and also gradually block some entrances of both macro-pores and micro-pores. This may explain the small shift of the modal size of both macro-pore and micro-pore populations. As the new phase filled the pores and blocked the pore entrances, initially un-constricted pores can become constricted pores, leading to a decrease in the total intrusion value (Wang et al., 2015). This is in agreement with the observation by Russo and Modoni (2013).

\section{Conclusion}

The changes in mineralogical composition and microstructure of a lime-treated compacted soil during curing were investigated, with emphasis on the effect of aggregate size. On the basis of the experimental results, some conclusions can be drawn, as follows:

1) XRD peaks of calcium silicate hydrates (C-S-H) on crystallized tobermorite form were 
observed on patterns of freeze-dried lime-treated soil sample with large aggregates (S5 and S1) after 1-year curing, while no such C-S-H was observed at shorter curing times. Oven-drying at $105^{\circ} \mathrm{C}$ allowed confirming the mineralogical nature of the new formed phase as C-S-H. 
The authors wish to acknowledge the support of the European Commission via the Marie

Curie IRSES project GREAT - Geotechnical and geological Responses to climate change: Exchanging Approaches and Technologies on a world-wide scale (FP7-PEOPLE-2013-IRSES- 612665). The support from China Scholarship Council (CSC) and Ecole des Ponts ParisTech are also gratefully acknowledged.

\section{References}

Al-Mukhtar, M., Lasledj, A., Alcover, J. F., 2010. Behaviour and mineralogy changes in lime-treated expansive soil at $20^{\circ} \mathrm{C}$. Applied Clay Science 50(2), 191-198.

Al-Mukhtar, M., Lasledj, A., Alcover, J. F., 2014. Lime consumption of different clayey soils. Applied Clay Science 95, 133-145.

Alvarez, J. I., Fernandez, J. M., Navarro-Blasco, I., Duran, A., Sirera, R., 2013. Microstructural consequences of nanosilica addition on aerial lime binding materials: Influence of different drying conditions. Materials Characterization 80, 36-49.

Arabi, M., Wild, S., 1986. Microstructural development in cured soil-lime composites. Journal of Materials Science 21(2), 497-503.

Bell, F. G., 1989. Lime stabilisation of clay soils. Bulletin of the International Association of Engineering Geology 39(1), 67-74.

Bell, F. G., 1996. Lime stabilization of clay minerals and soils. Engineering Geology 42(4), 223-237.

Boardman, D. I., Glendinning, S., Rogers, C. D. F., 2001. Development of stabilisation and 
solidification in lime-clay mixes. Géotechnique 51(6), 533-543.

Bozbey, I., Guler, E., 2006. Laboratory and field testing for utilization of an excavated soil as landfill liner material. Waste Management 26(11), 1277-1286.

Brunauer, S., 1962. Tobermorite gel-the heart of concrete. American Scientist 50(1), 210-229.

Cai, G. H., Du, Y. J., Liu, S. Y., Singh, D. N., 2015. Physical properties, electrical resistivity, and strength characteristics of carbonated silty soil admixed with reactive magnesia. Canadian Geotechnical Journal 52(11), 1699-1713.

Carter, J. R., Hatcher, M. T., Di Carlo, L., 1987. Quantitative analysis of quartz and cristobalite in bentonite clay based products by X-ray diffraction. Analytical Chemistry 59(3), 513-519.

Collier, N. C., Sharp, J. H., Milestone, N. B., Hill, J., Godfrey, I. H., 2008. The influence of water removal techniques on the composition and microstructure of hardened cement pastes. Cement and Concrete Research 38(6), 737-744.

Consoli, N.C., Lopes, L.S., Heineck, K.S., 2009. Key parameters for the strength control of lime stabilized soils. Journal of Materials in Civil Engineering 21(5), 210-216.

Cuisinier, O., Deneele, D., 2008. Impact of cyclic wetting and drying on the swelling properties of a lime-treated expansive clay. Jourées Nationales de Géotechnique et de Géologie de l’Ingénieur JNGG’08, Nantes, 18-20.

Delage, P., Pellerin, F.M., 1984. Influence de la lyophilisation sur la structure d'une argile sensible du Québec. Clay Minerals 19(2), 151-160. 
Deneele, D., Lemaire, K., 2012. Evaluation de la durabilité des sols - Effet de la circulation d'eau sur la durabilité du limon traité_Approche multi - échelle, Livrables du projet TerDOUEST (Terrassement Durables - Ouvrages En Sols Traités, 2008-2012).

Dong, J., 2013. Investigation of aggregates size effect on the stiffness of lime and/or cement treated soil: from laboratory to field conditions. PhD Dissertation, Ecole Nationale des Ponts et Chaussées, France.

Du, Y. J., Jiang, N. J., Liu, S. Y., Jin, F., Singh, D. N., Puppala, A. J., 2014. Engineering properties and microstructural characteristics of cement-stabilized zinc-contaminated kaolin. Canadian Geotechnical Journal 51(3), 289-302.

Eades, J. L., Grim, R. E., 1960. Reaction of hydrated lime with pure clay minerals in soil stabilization. Highway Research Board Bulletin 262, 51-63.

El-Hemaly, S. A. S., Mitsuda, T., Taylor, H. F. W., 1977. Synthesis of normal and anomalous tobermorites. Cement and Concrete Research 7(4), 429-438.

Gallé, C., 2001. Effect of drying on cement-based materials pore structure as identified by mercury intrusion porosimetry: a comparative study between oven-, vacuum-, and freeze-drying. Cement and Concrete Research 31(10), 1467-1477.

Glenn, G. R., Handy, R. L., 1963. Lime-clay mineral reaction products. Highway Research Record 29, 70-82.

Goldberg, I., Klein, A., 1953. Some effects of treating expansive clays with calcium hydroxide. In Symposium on Exchange Phenomena in Soils. ASTM International 142, 53-71.

Guney, Y., Sari, D., Cetin, M., Tuncan, M., 2007. Impact of cyclic wetting-drying on swelling 
behavior of lime-stabilized soil. Building and Environment 42(2), 681-688.

Hilt, G. H., Davidson, D. T., 1960. Lime fixation in clayey soils. Highway Research Board Bulletin 262, 20-32.

Horpibulsuk, S., Katkan, W., Sirilerdwattana, W., Rachan, R., 2006. Strength development in cement stabilized low plasticity and coarse grained soils: Laboratory and field study. Soils and foundations 46(3), 351-366.

Jiang, N. J., Du, Y. J., Liu, S. Y., Wei, M. L., Horpibulsuk, S., Arulrajah, A., 2016. Multi-scale laboratory evaluation of the physical, mechanical, and microstructural properties of soft highway subgrade soil stabilized with calcium carbide residue. Canadian Geotechnical Journal 53(3), 373-383.

Kavak, A., Akyarlı, A., 2007. A field application for lime stabilization. Environmental geology 51(6), 987-997.

Kemper, W., Chepil, W., 1965. Size distribution of aggregates. Methods of Soil Analysis. Part 1. Physical and Mineralogical Properties, Including Statistics of Measurement and Sampling, no methodsofsoilana, 499-510.

Khattab, S. A., Al-Mukhtzr, M., Fleureau, J. M., 2007. Long-term stability characteristics of a lime-treated plastic soil. Journal of Materials in Civil Engineering 19(4), 358-366.

Khattab, S. A., 2002. Etude multi-échelles d'un sol argileux plastique traité à la chaux. Doctoral dissertation, Orléans.

Maubec, N., 2011. Approche multi-échelle du traitement des sols à la chaux études des interactions avec les argiles. Doctoral dissertation, Université de Nantes. 
Merlino, S., Bonaccorsi, E. and Armbruster, T. 1999. Tobermorites: their real structure and order-disorder (OD) character. American Mineralogist, 84: 1613-1621.

Merlino, S., Bonaccorsi, E. and Armbruster, T. 2000. The real structures of clinotobermorite and tobermorite $9 \AA$ A: OD character, polytypes, and structural relationships. European Journal of Mineralogy, 12,411-429.

Merlino, S., Bonaccorsi, E., and Armbruster, T. 2001: The real structure of tobermorite-11 normal and anomalous forms, OD character and polytypic modifications. European Journal of Mineralogy 13(3), 577-590.

Mitchell, J. K., 1993. Fundamentals of Soil Behavior. John Wiley and Sons, Inc., New York, 437.

Moon, D. H., Dermatas, D., Menounou, N., 2004. Arsenic immobilization by calcium-arsenic precipitates in lime treated soils. Science of the Total Environment 330(1), 171-185.

Nalbantoglu, Z., 2006. Lime stabilization of expansive clay. Expansive soils-recent advances in characterization and treatment. London, Taylor \& Francis group, 341-348.

Onitsuka, K., Modmoltin, C., Kouno, M., 2001. Investigation on microstructure and strength of lime and cement stabilized ariake clay. Reports of The Faculty of Science and Engineering Saga University 30(1), 49-63.

Pardini, G., Guidi, G. V., Pini, R., Regüés, D., Gallart, F., 1996. Structure and porosity of smectitic mudrocks as affected by experimental wetting-drying cycles and freezing - thawing cycles. Catena 27(3), 149-165.

Ping, X., Beaudoin, J. J., Brousseau, R., 1991. Effect of aggregate size on transition zone 
properties at the portland cement paste interface. Cement and Concrete Research 21(6), 999-1005.

Puppala, A. J., Kadam, R., Madhyannapu, R. S., Hoyos, L. R., 2006. Small-strain shear moduli of chemically stabilized sulfate-bearing cohesive soils. Journal of Geotechnical and Geoenvironmental Engineering 132(3), 322-336.

Rajasekaran, G., Narasimha Rao, S., 2002. Compressibility behaviour of lime-treated marine clay. Ocean engineering 29(5), 545-559.

Ríos, C. A., Williams, C. D., Fullen, M. A., 2009. Hydrothermal synthesis of hydrogarnet and tobermorite at $175{ }^{\circ} \mathrm{C}$ from kaolinite and metakaolinite in the $\mathrm{CaO}-\mathrm{Al}_{2} \mathrm{O}_{3}-\mathrm{SiO}_{2}-\mathrm{H}_{2} \mathrm{O}$ system: a comparative study. Applied Clay Science 43(2), 228-237. of compacted clayey soils. Géotechnique 61(4), 313-328.

Russo, G., Modoni, G., 2013. Fabric changes induced by lime addition on a compacted alluvial soil. Géotechnique Letters 3(2), 93-97.

Russo, G., 2005. Water retention curves of lime stabilised soil. Advanced Experimental Unsaturated Soil Mechanics. Taylor \& Francis, London, 391-396. of a lime-treated expansive clayey soil. Applied Clay Science 61, 44-51. on the stiffness of a lime-treated clayey soil. Géotechnique 61, 421-429. 

on the microstructure and hydraulic conductivity of Héricourt clay. Journal of Rock Mechanics and Geotechnical Engineering 6(5), 399-404. on water retention capacity and microstructure of lime-treated silty soil. Géotechnique Letters 5(4), 269-274.

Wang, Y., Cui, Y., Tang, A. M., Tang, C., Benahmed, N., 2016. Changes in thermal conductivity, suction and microstructure of a compacted lime-treated silty soil during curing. Engineering Geology (202), 114-121.Wild, S., Arabi, M., Leng-Ward, G., 1986. Soil-lime reaction and microstructural development at elevated temperatures. Clay Minerals 21(3), 279-292.

Willoughby, D. R., Gross, K. A., Ingles, O. G., Silva, S. R., Spiers, V. M., 1968. The Identification of Reaction Products in Alkali-Stabilized Clays by Electron Microscopy, X-ray and Electron Diffraction. In: Proceedings of the 4th Conference of Australian Board 4, 386-1408. 
Table 1 ESEM-EDAX element analysis of S1 at a curing time of $t=1$ day, both on the spots where lime

\begin{tabular}{|c|c|c|c|c|c|c|}
\hline \multirow{2}{*}{ Element } & \multicolumn{2}{|c|}{$\mathrm{Wt} \%$} & \multicolumn{2}{|c|}{ At $\%$} & \multicolumn{2}{|c|}{ K-Ratio } \\
\hline & Lime & Clay & Lime & Clay & Lime & Clay \\
\hline $\mathrm{C}$ & 6.37 & 4.28 & 10.85 & 7.23 & 0.0171 & 0.0068 \\
\hline $\mathrm{O}$ & 50.54 & 49.47 & 64.67 & 62.74 & 0.0959 & 0.1652 \\
\hline $\mathrm{Na}$ & 0.14 & 0.21 & 0.12 & 0.19 & 0.0004 & 0.0007 \\
\hline $\mathrm{Mg}$ & 0.77 & 0.73 & 0.65 & 0.61 & 0.0035 & 0.0036 \\
\hline $\mathrm{Al}$ & 3.65 & 10.18 & 2.77 & 7.65 & 0.021 & 0.0624 \\
\hline $\mathrm{Si}$ & 7.71 & 22.88 & 5.62 & 16.53 & 0.0529 & 0.1496 \\
\hline $\mathrm{K}$ & 0.39 & 1.76 & 0.2 & 0.91 & 0.0037 & 0.015 \\
\hline $\mathrm{Ca}$ & 27.38 & 2.06 & 13.99 & 1.04 & 0.2574 & 0.0185 \\
\hline $\mathrm{Ti}$ & 0.28 & 0.59 & 0.12 & 0.25 & 0.0022 & 0.0051 \\
\hline $\mathrm{Fe}$ & 2.78 & 7.83 & 1.02 & 2.85 & 0.0236 & 0.0683 \\
\hline
\end{tabular}


Table 2 ESEM-EDAX element analysis of S1 at a curing time of $t=1$ year, on the spot where CSH located

$\begin{array}{llll}\text { Element } & \text { Wt } \% & \text { At } \% & \text { K-Ratio }\end{array}$

\begin{tabular}{|c|c|c|c|}
\hline $\mathrm{C}$ & 3.33 & 5.61 & 0.0064 \\
\hline $\mathrm{O}$ & 52.49 & 66.42 & 0.1295 \\
\hline $\mathrm{Na}$ & 0 & 0 & 0 \\
\hline $\mathrm{Mg}$ & 2.32 & 1.93 & 0.0113 \\
\hline $\mathrm{Al}$ & 6.83 & 5.12 & 0.0407 \\
\hline $\mathrm{Si}$ & 16.54 & 11.92 & 0.1112 \\
\hline $\mathrm{K}$ & 0.41 & 0.21 & 0.0037 \\
\hline $\mathrm{Ca}$ & 15.55 & 7.85 & 0.1421 \\
\hline $\mathrm{Ti}$ & 0.17 & 0.07 & 0.0014 \\
\hline $\mathrm{Fe}$ & 2.37 & 0.86 & 0.0203 \\
\hline
\end{tabular}


Table 3 ESEM-EDAX element analysis of S0.4 at a curing time of $t=1$ year, on the spot where CSH 548 located

\begin{tabular}{cccc}
\hline Element & Wt $\%$ & At $\%$ & K-Ratio \\
\hline $\mathrm{C}$ & 7.1 & 11.32 & 0.0147 \\
\hline $\mathrm{O}$ & 55.15 & 66.01 & 0.1435 \\
\hline $\mathrm{Mg}$ & 1.89 & 1.49 & 0.009 \\
\hline $\mathrm{Al}$ & 6.3 & 4.47 & 0.0372 \\
\hline $\mathrm{Si}$ & 14.2 & 9.68 & 0.0953 \\
\hline $\mathrm{K}$ & 0.25 & 0.12 & 0.0201 \\
\hline $\mathrm{Fa}$ & 12.78 & 6.11 & 0.1171 \\
\hline
\end{tabular}


Figure 1 Aggregate size distribution of soil S5, S1 and S0.4

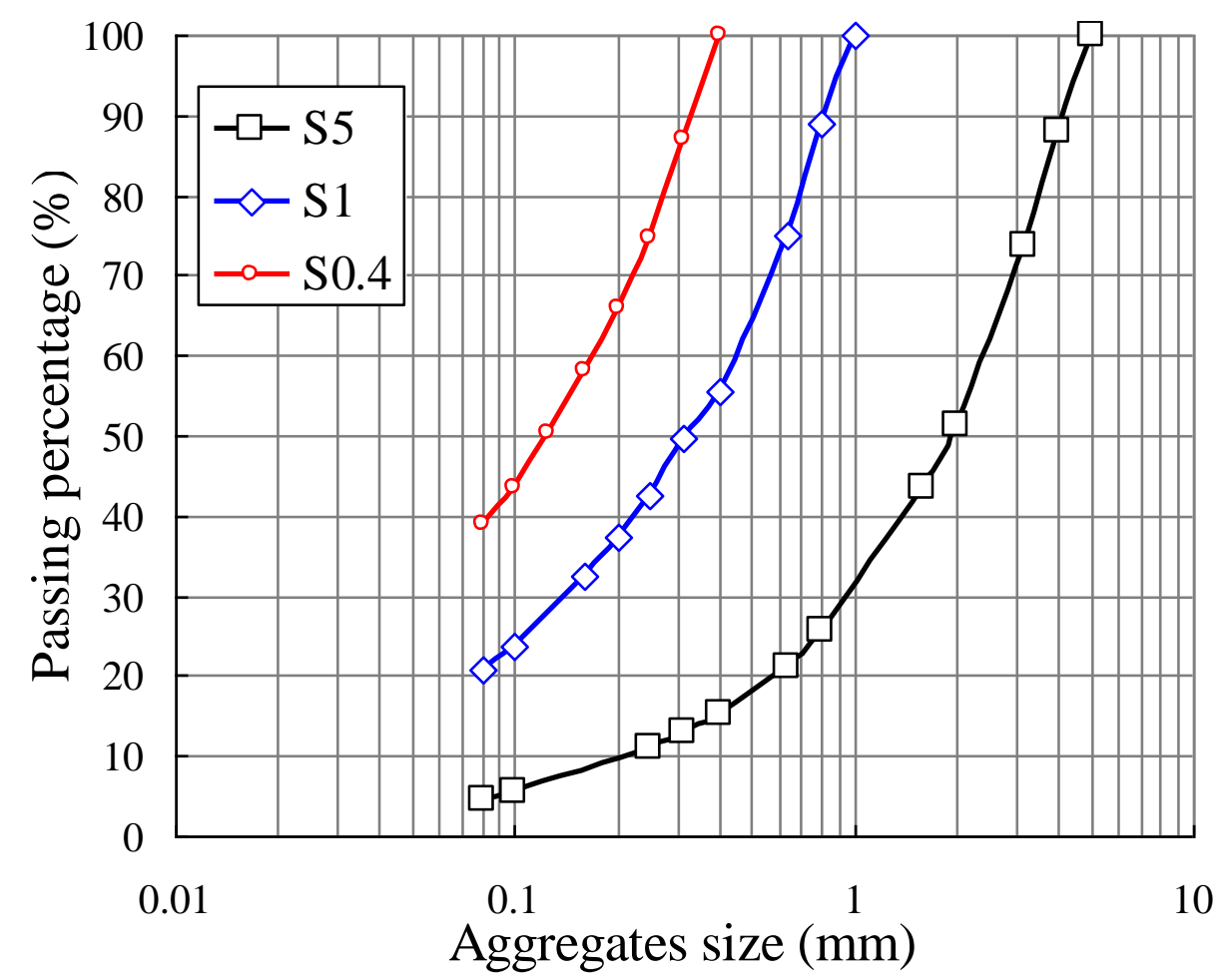


Figure 2 X-ray diffraction patterns of the untreated soil S1

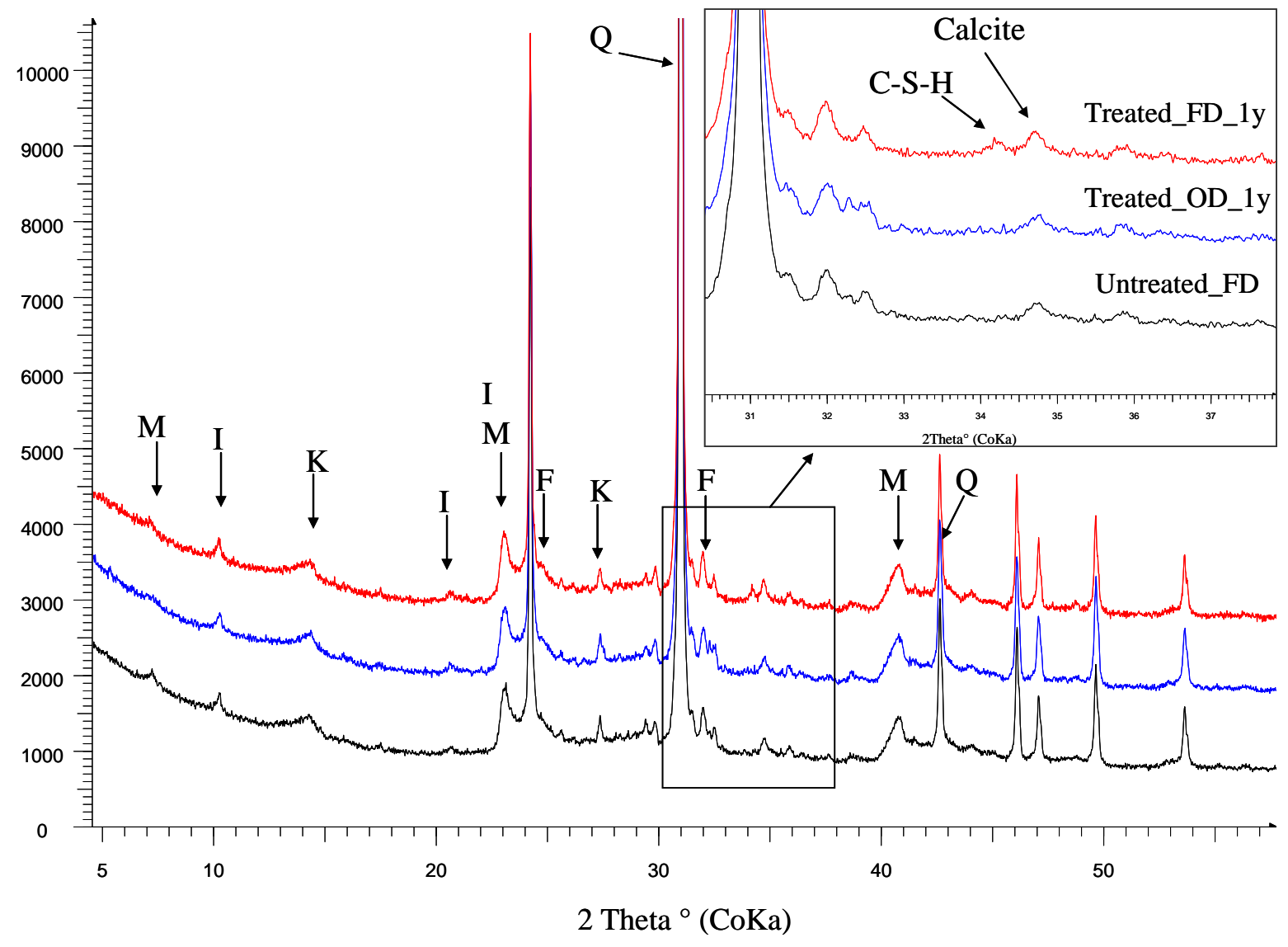


559 Figure 3 X-ray diffraction patterns of lime-treated soils during curing: (a) S5; (b) S0.4

(a)

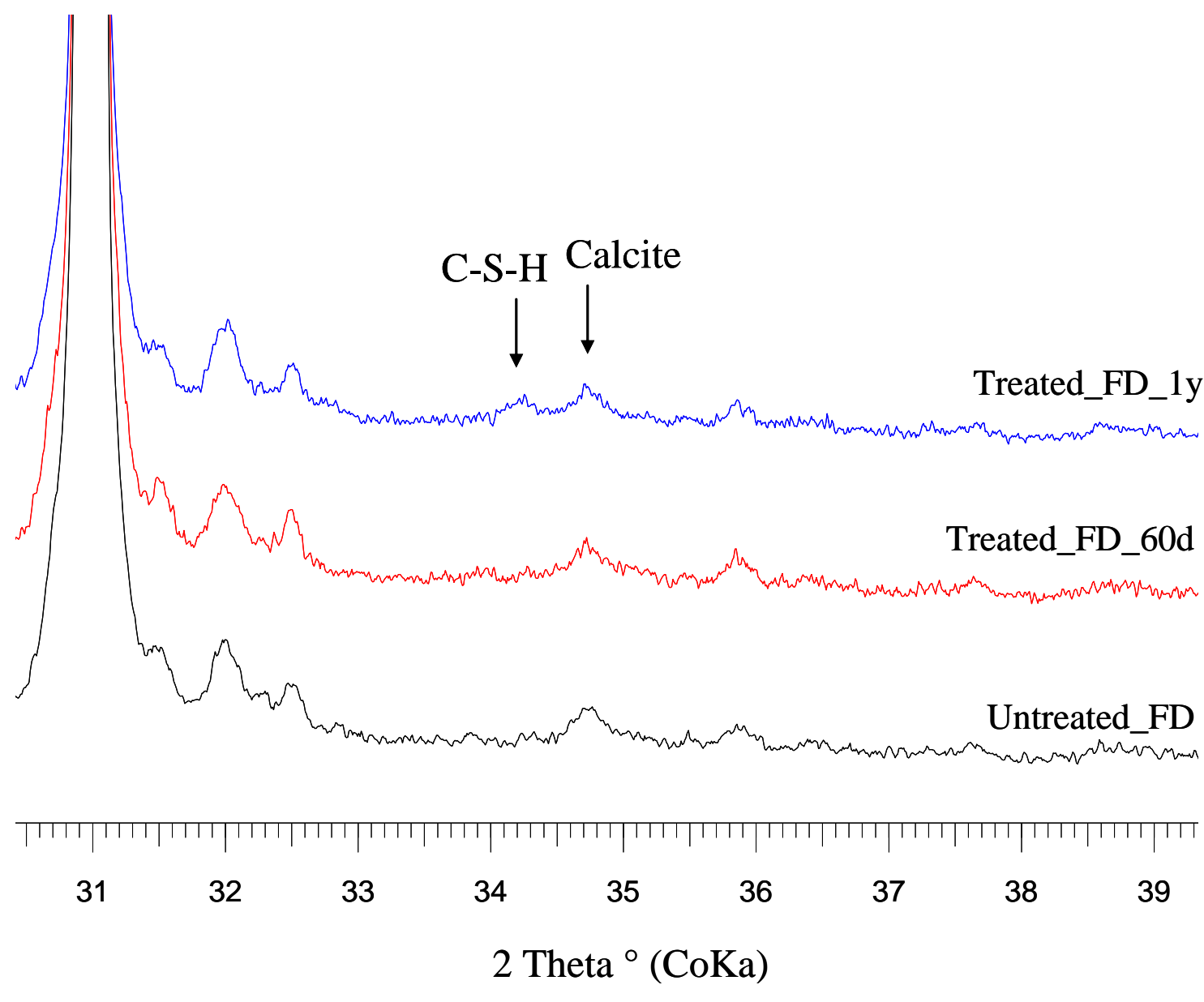


(b)

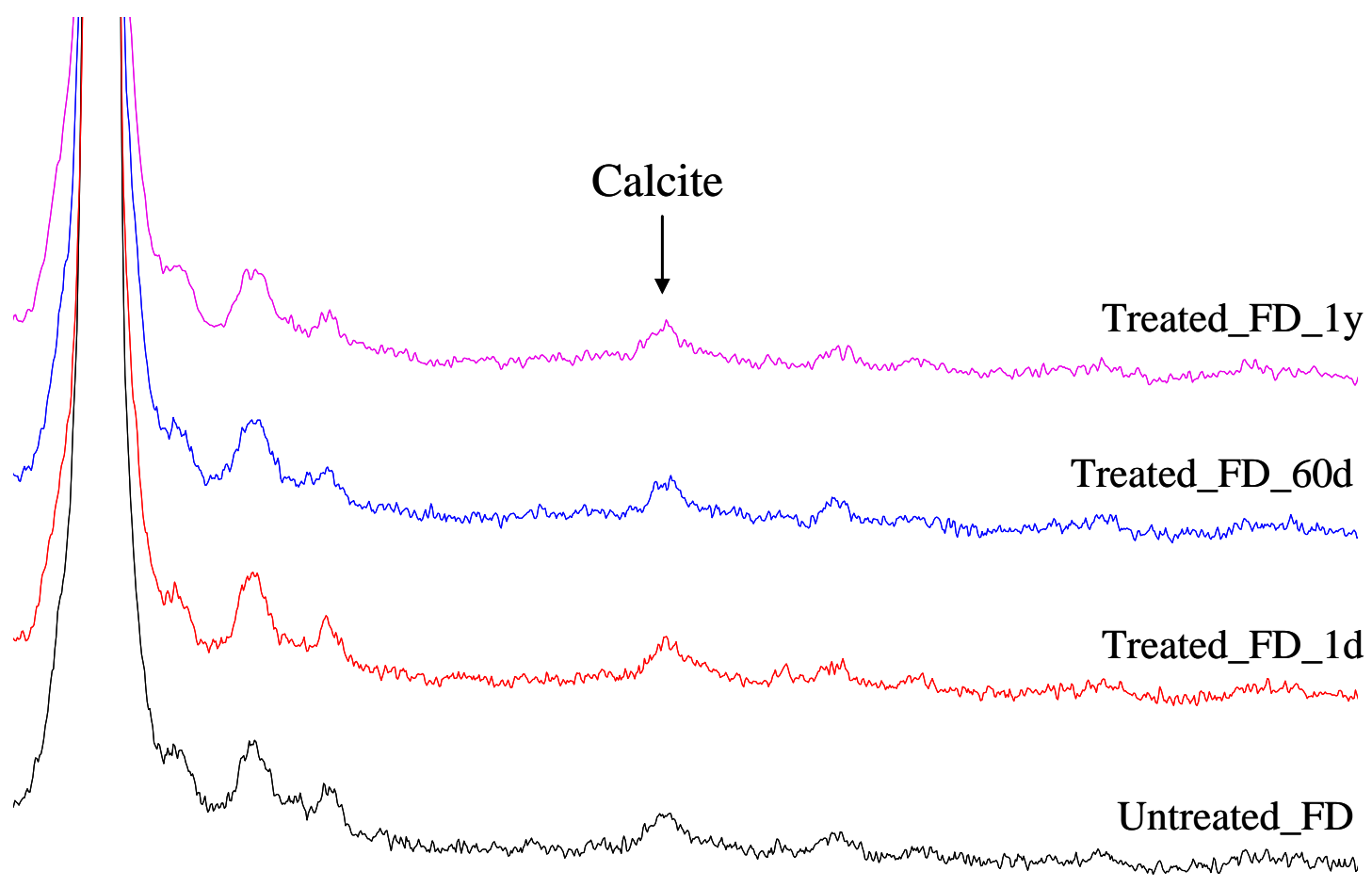

\begin{tabular}{|c|c|c|c|c|c|c|c|c|}
\hline 31 & 32 & 33 & 34 & 35 & 36 & 37 & 38 & 39 \\
\hline
\end{tabular}

562 
565 Figure 4 Elementary distribution maps of a lime-treated soil, S1, at a curing time of $t=1$ day: (a) Silicium;

566 (b) Aluminium; (c) Calcium, and SEM picture of the spot in the calcium concentration area

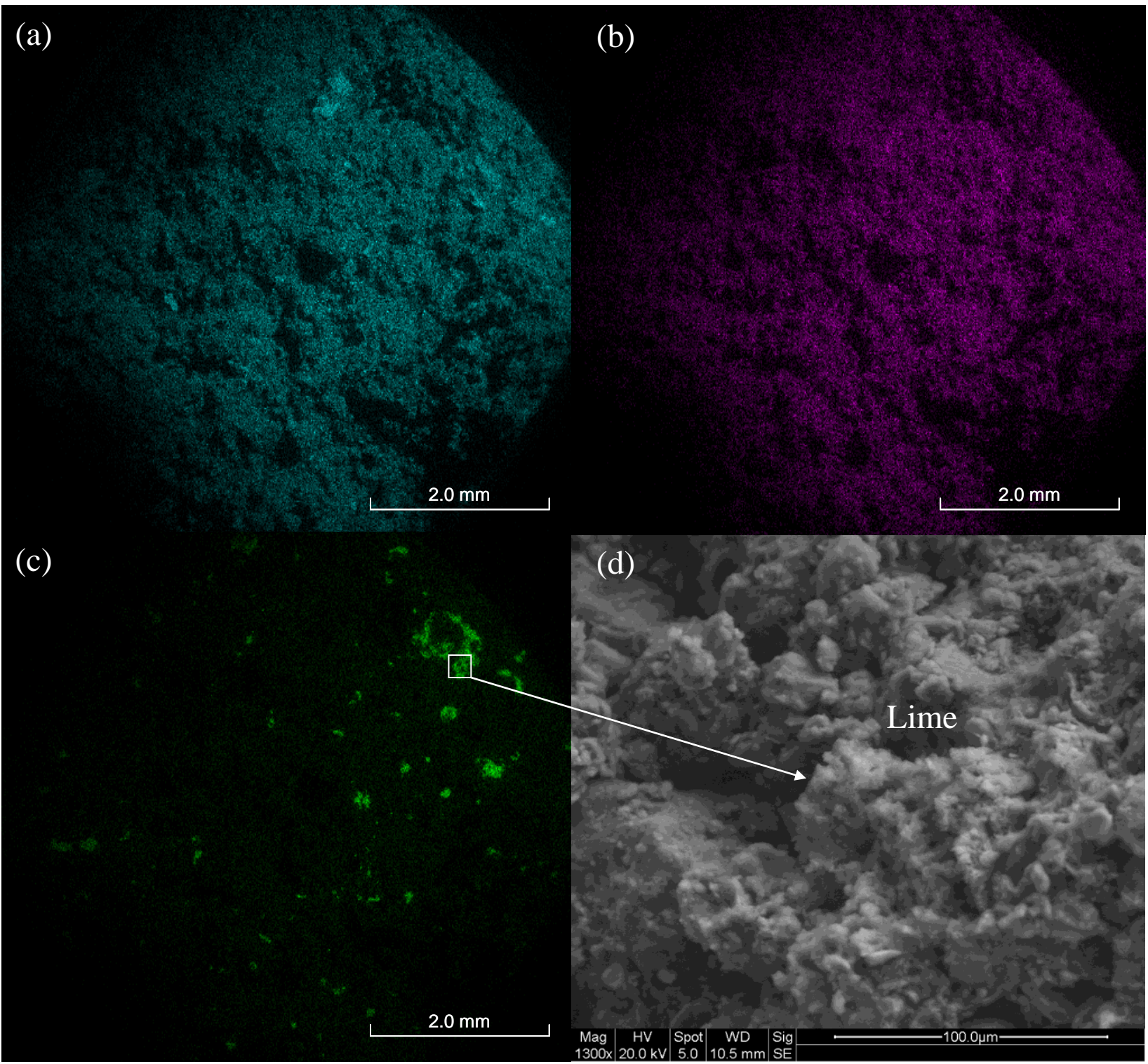


Figure 5 Element examination by EDAX on lime-treated soil S1 at a curing time of $t=1$ day: (a) on the spot in the calcium concentration area; (b) on the spot in the clay particle area

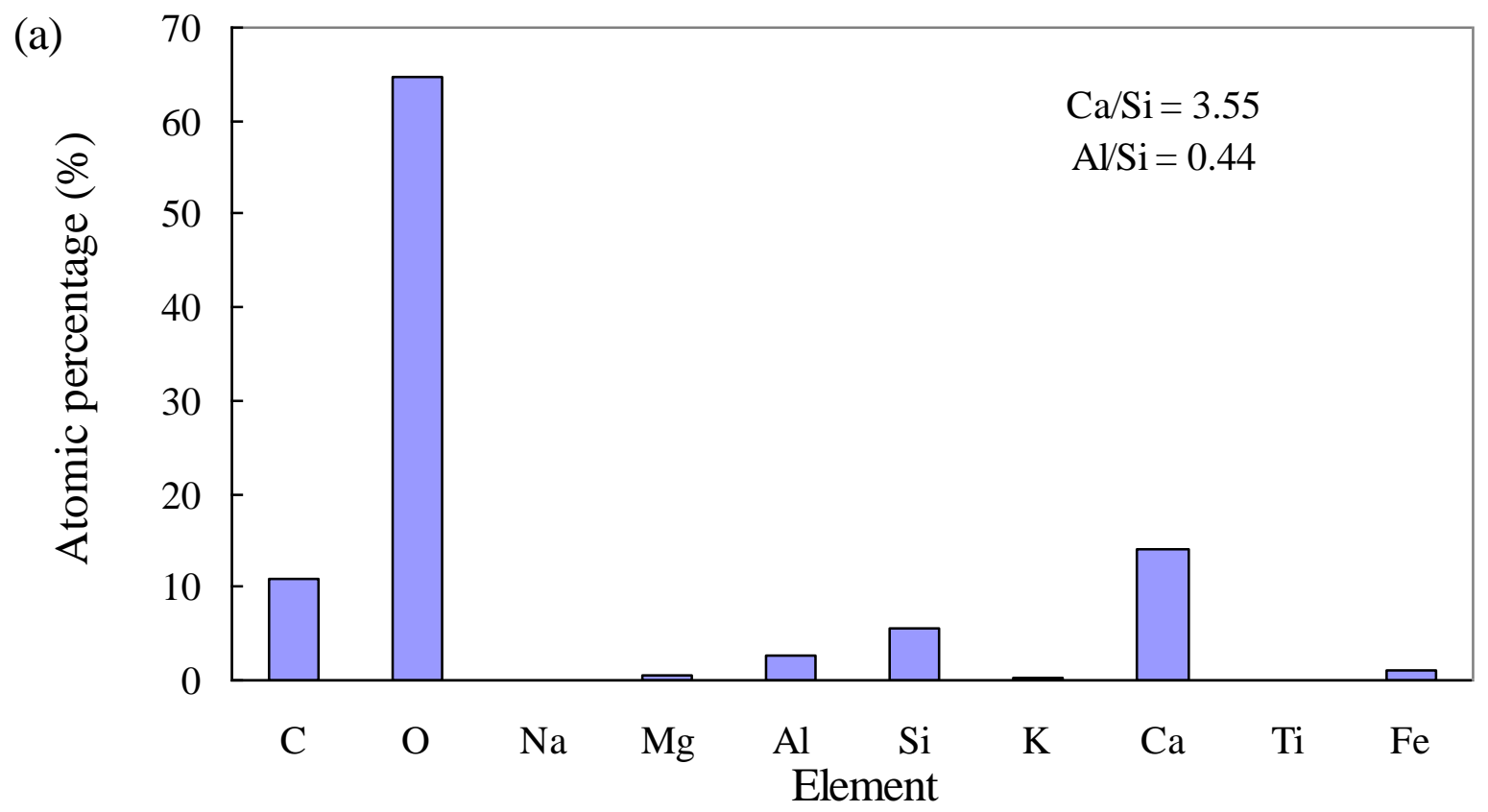

570

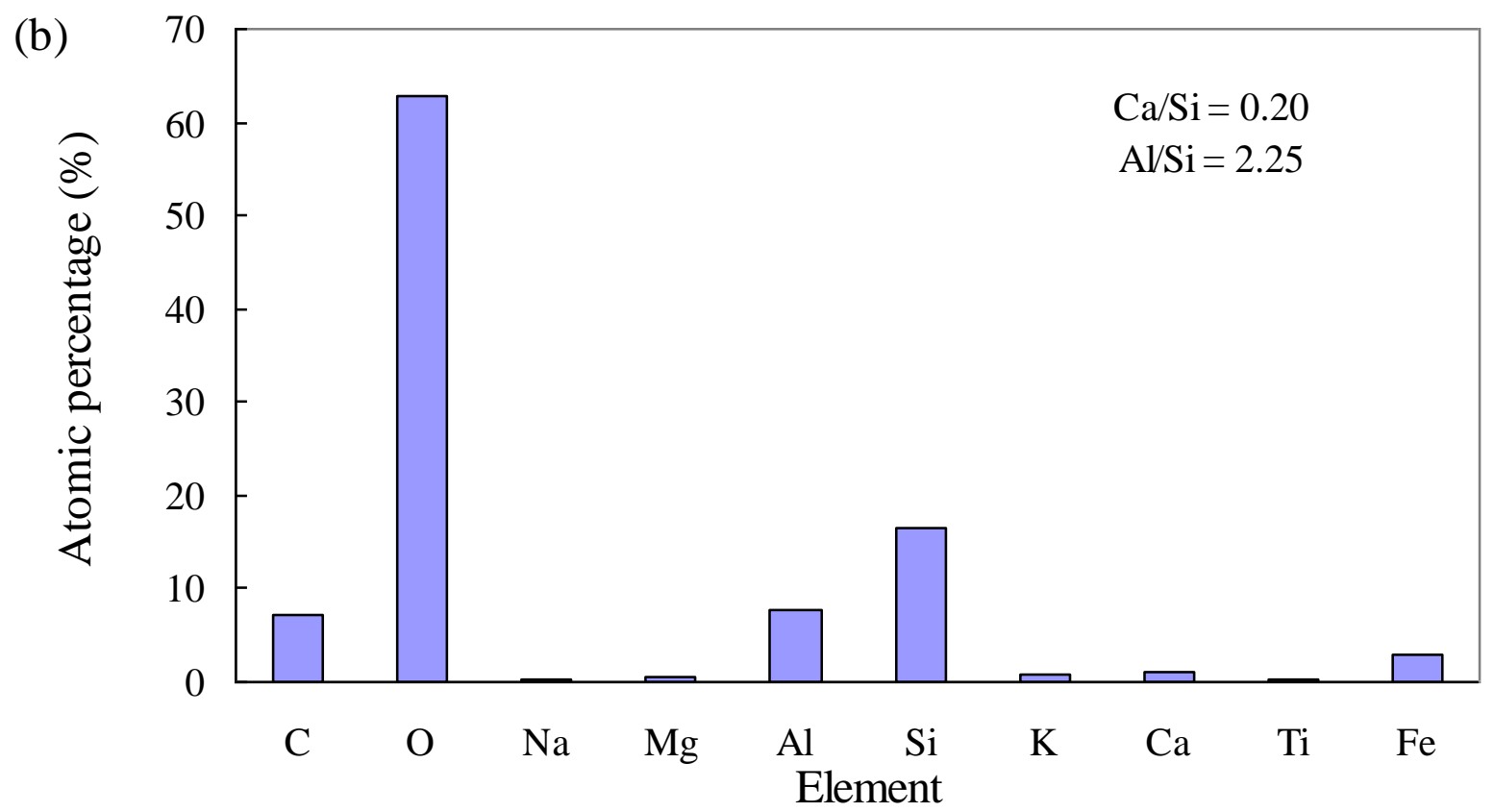


575 Figure 6 Elementary distribution maps of a lime-treated soil, S1, at a curing time of $t=1$ year: (a) Silicium;

576 (b) Aluminium; (c) Calcium, and SEM picture of the spot in the calcium concentration area

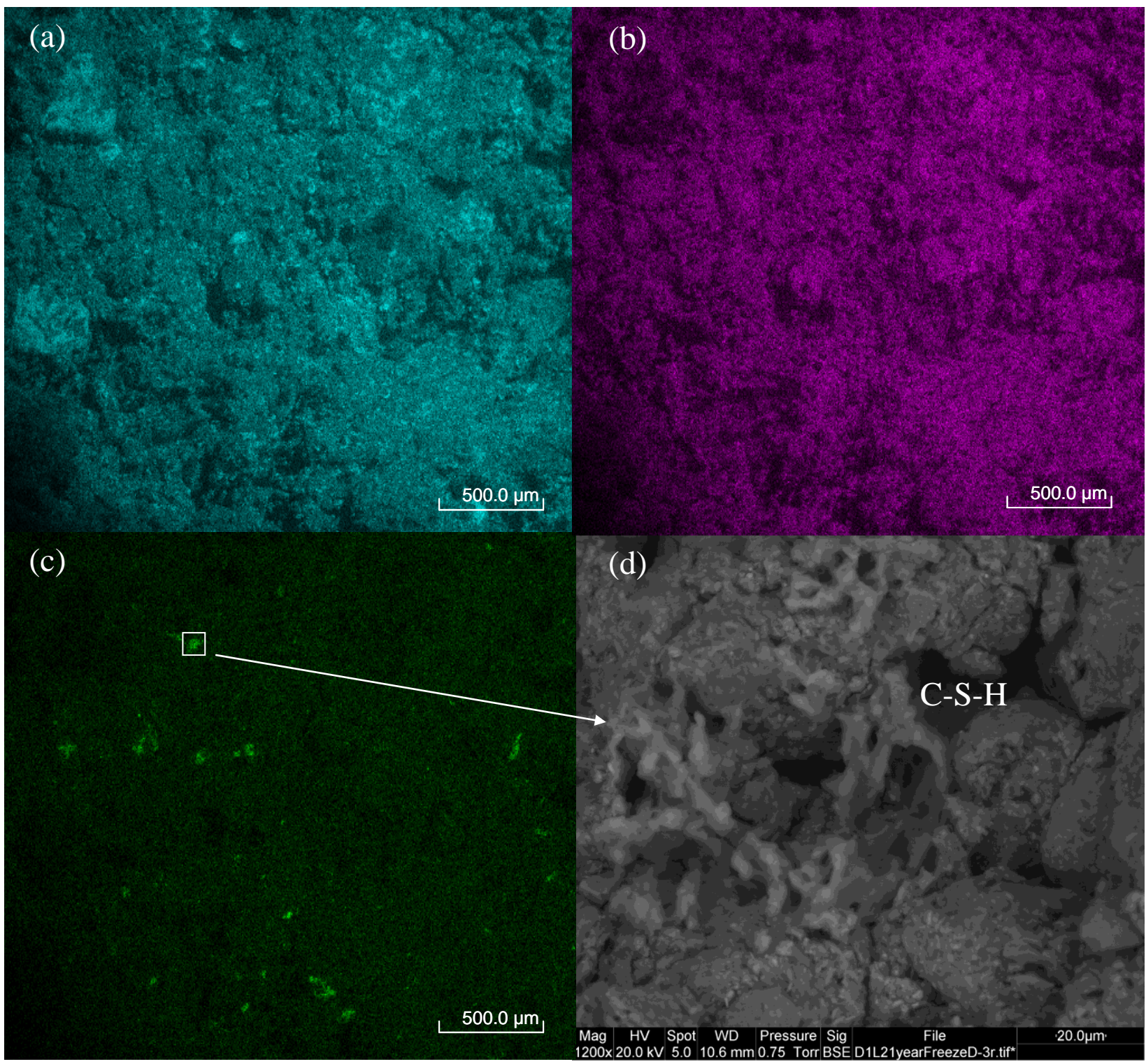



in the calcium concentration area

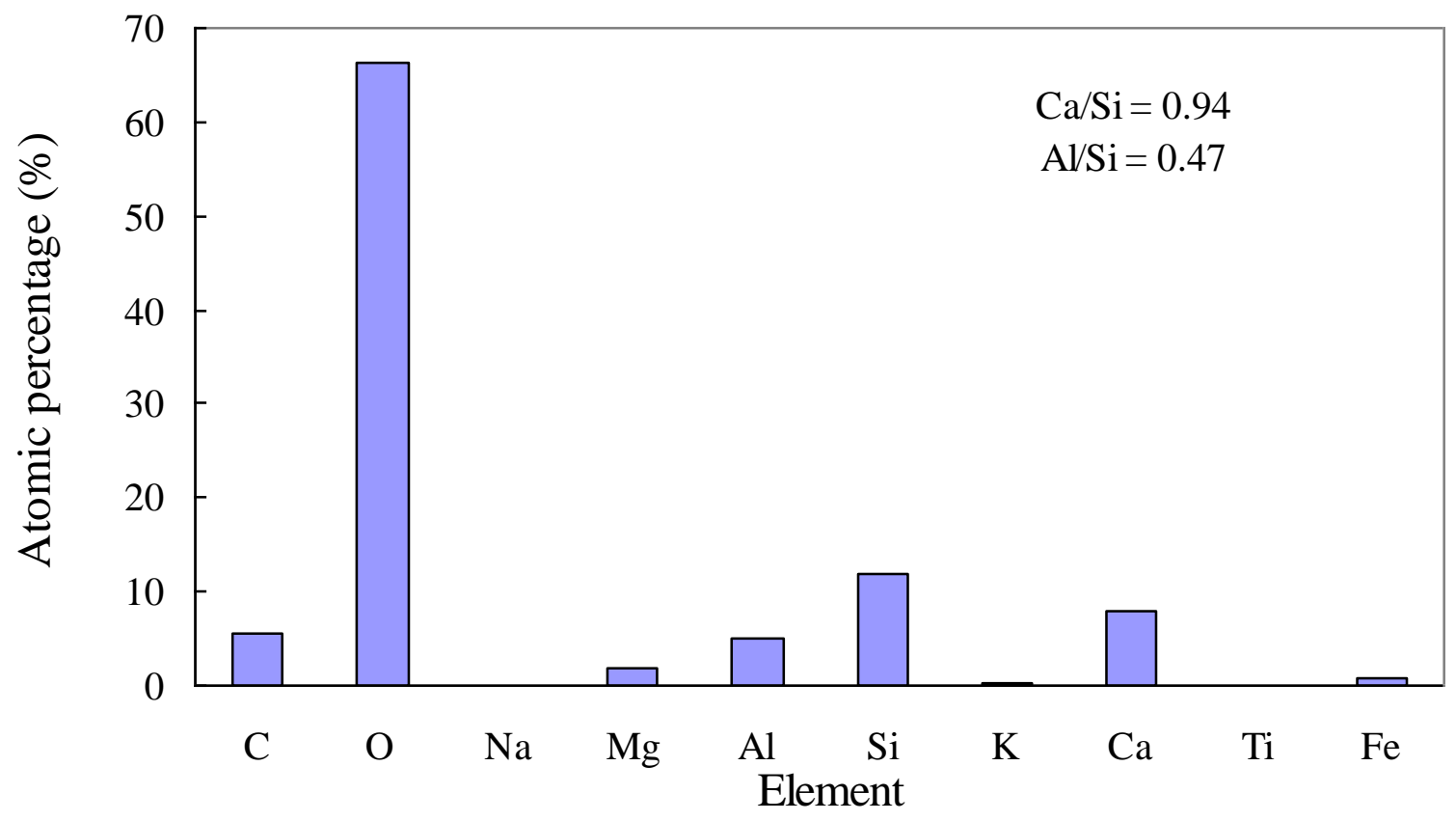

580 
584 Figure 8 SEM picture of the lime-treated soil, S04, at a curing time of $t=1$ year

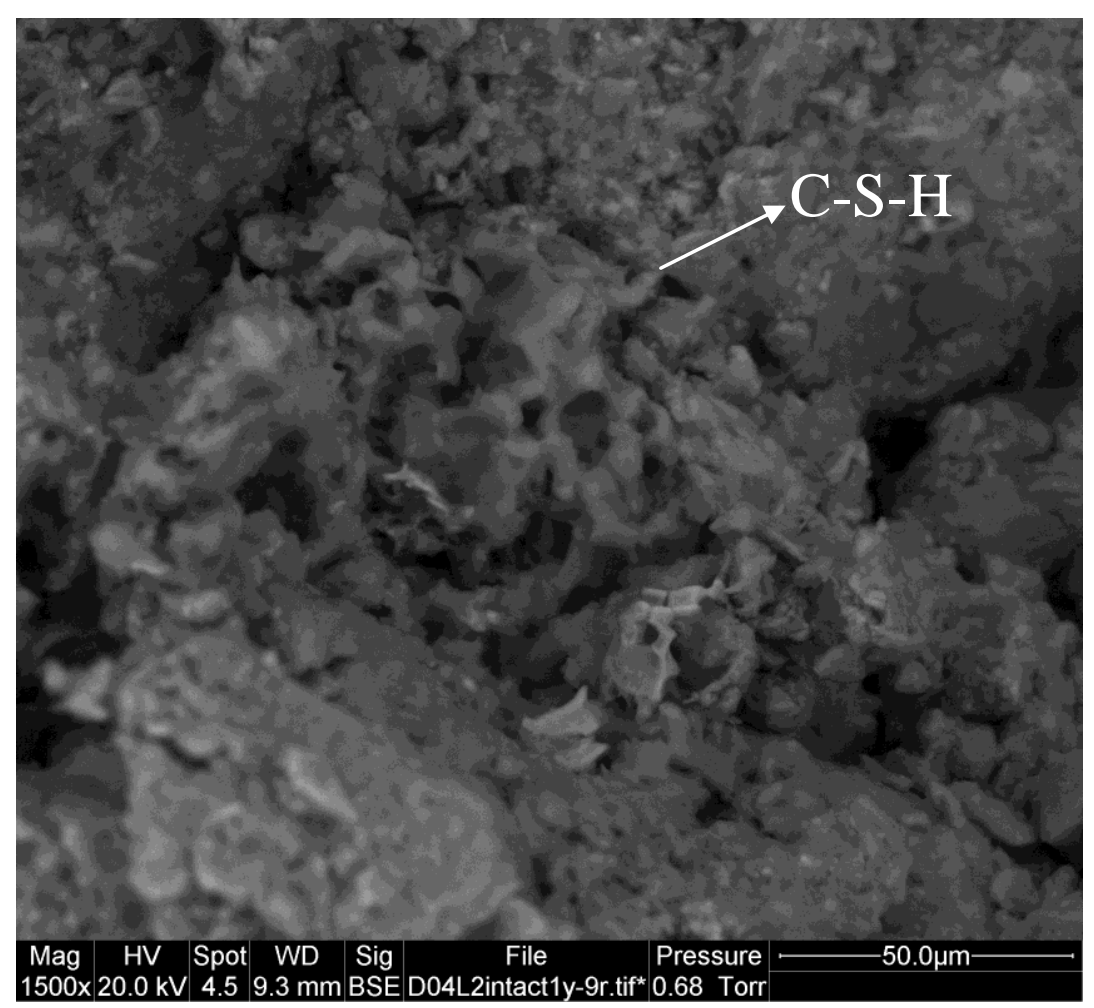


588 Figure 9 Element examination by EDAX on lime-treated soil S0.4 at a curing time of $t=1$ year, on the spot 589 in the calcium concentration area

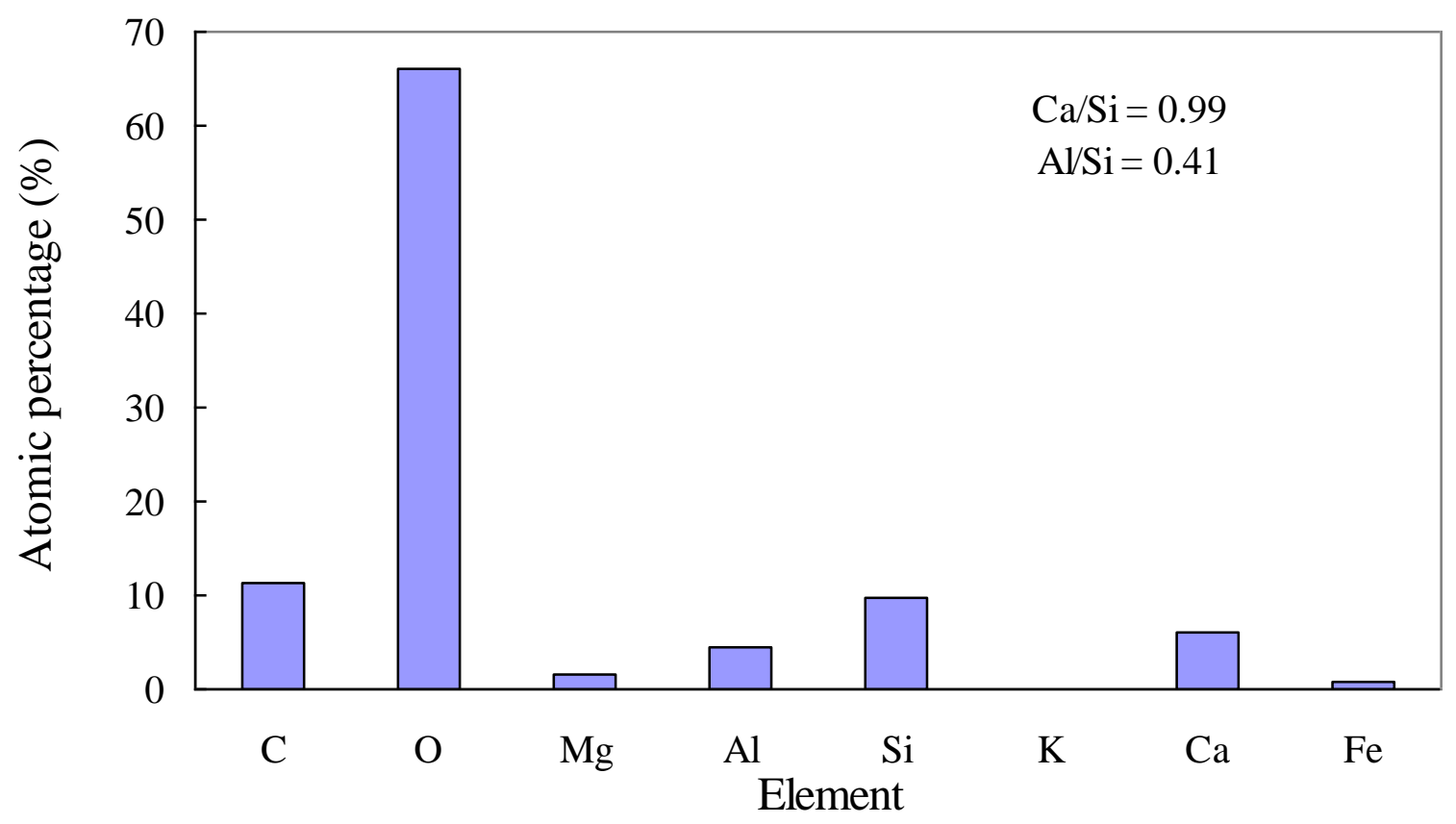

590 
592 Figure 10 Pore size distributions and cumulative intrusion curves of lime-treated soils with different 593 aggregate sizes (S5, S1 and S0.4), obtained by MIP

(a)

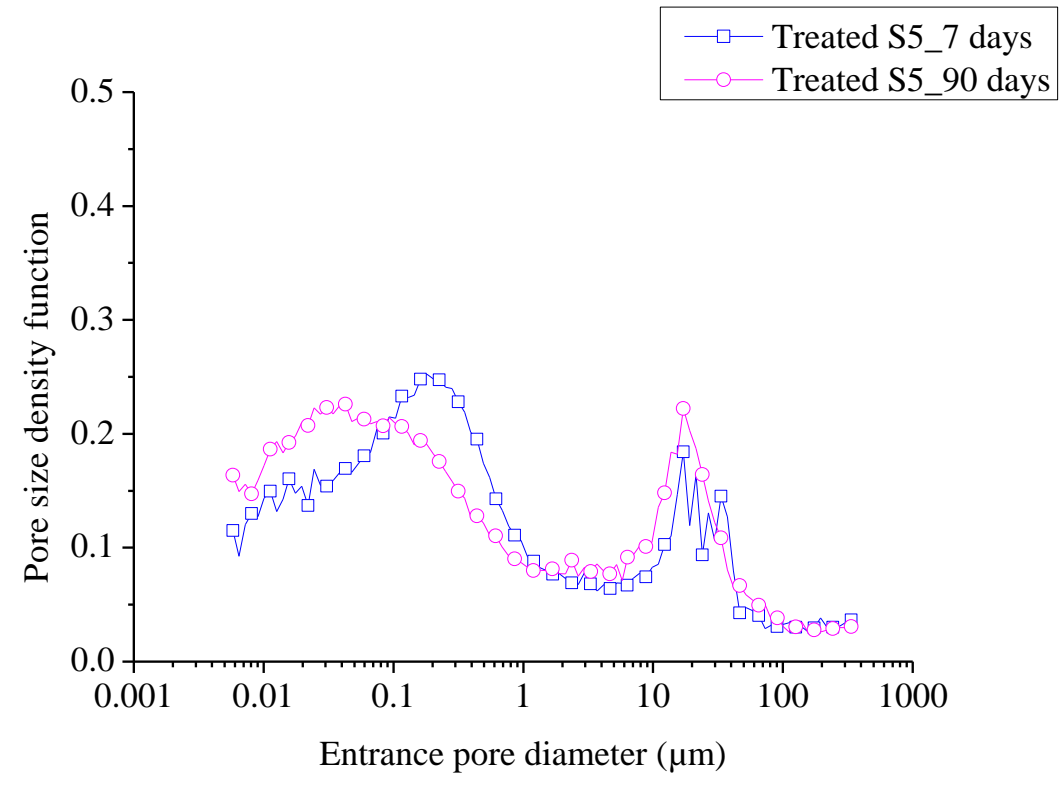

(b)

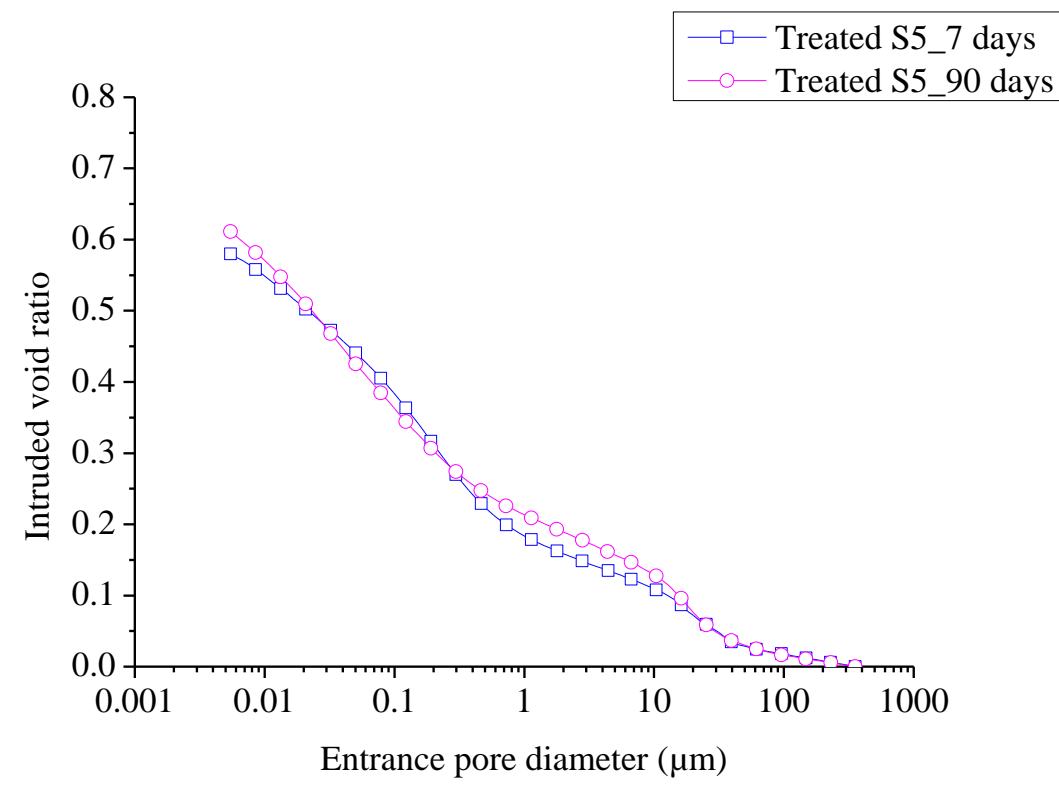


(c)

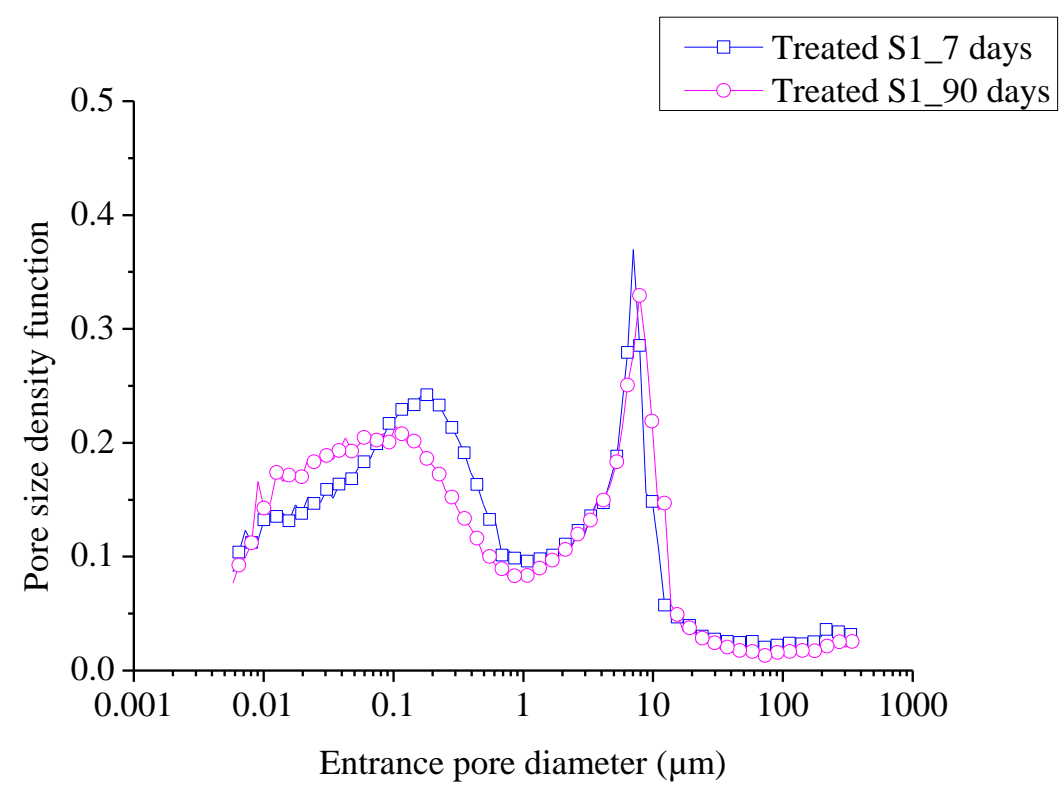

(d)

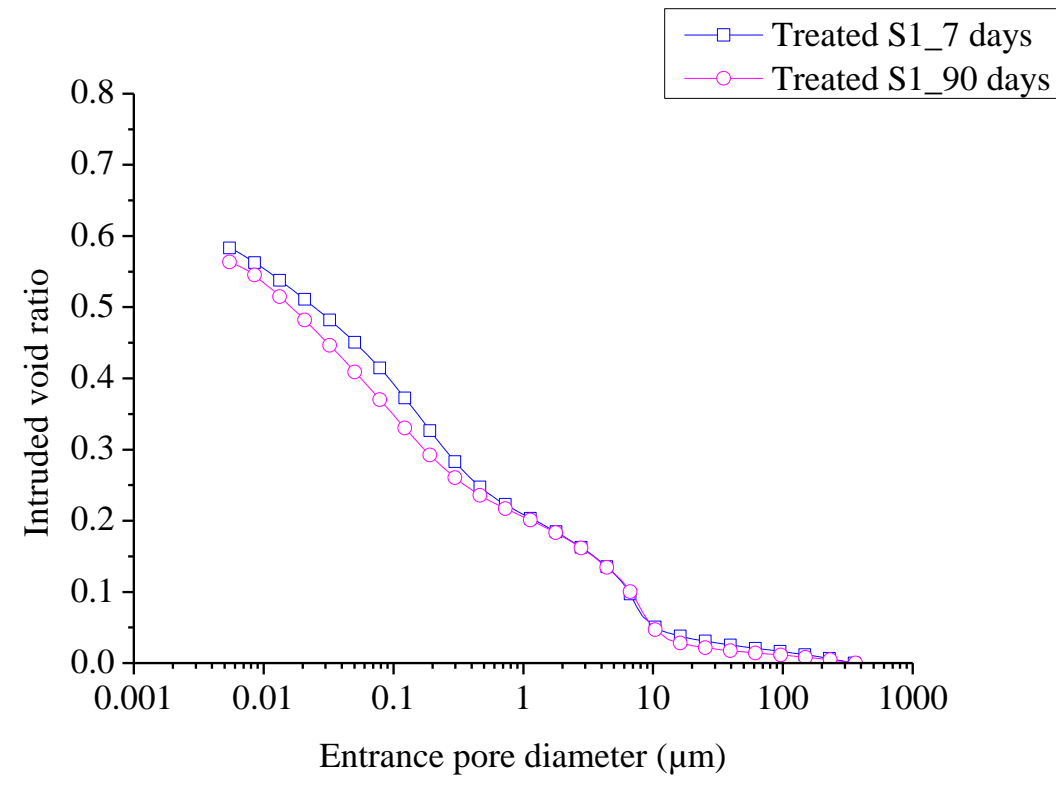


(e)

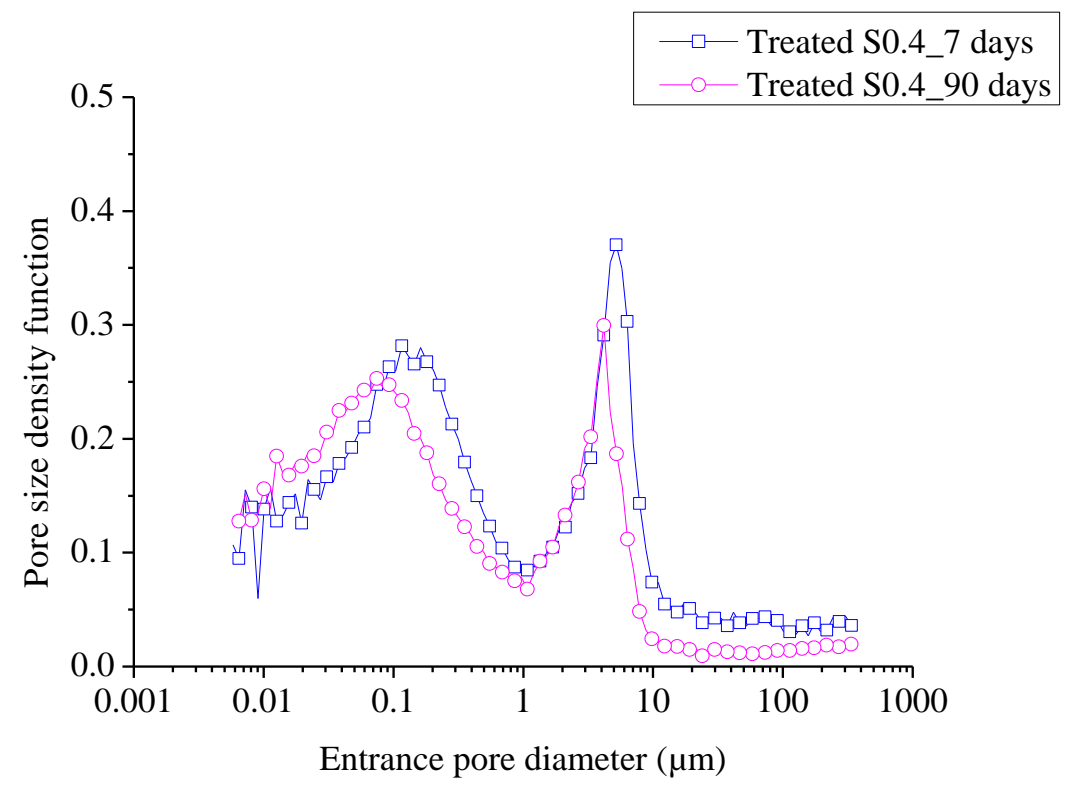

